Article

\title{
The Territory of the Grand Tetouan as Linear City: Between Description and Project
}

\author{
Victor Brunfaut * and Bertrand Terlinden \\ Faculty of Architecture La Cambre-Horta, Université Libre de Bruxelles, 1050 Brussels, Belgium; \\ E-Mails: victor.brunfaut@ulb.be (V.B.), bertrand.terlinden@ulb.ac.be (B.T.) \\ * Corresponding author
}

Submitted: 1 February 2020 | Accepted: 1 June 2020 | Published: 30 June 2020

\begin{abstract}
This article, based upon pedagogical experimentation in development in a master-level architecture studio at the ULB School of Architecture (Brussels), focuses on the concept of a linear city in a metropolitan context. This concept is proposed by the Grand Tetouan (North Morocco) spatial development scheme as a framework to think about the future of this territory. The interest of the concept lies in its being both a descriptive and project-oriented tool, which allows working with students on the intricate relationship between these two moments of urban design. The coastal region has been the subject of a proposal for a "linear garden city" by a follower of Soria y Mata, Hilarión González del Castillo (1929), a project that left traces on the "palimpsest" (Corboz, 1983/2001) of the actual territory. The idea of the linear city, which has been, throughout the 20th century, a recurrent thematic in urban planning theory and practice dealing with the issue of industrial development of the modern city can be, in the specific case of the Grand Tetouan region, re-examined through the lens of tourism as an industry. The exploration is based on an analytical approach by the use of the notion of urban material (Boeri, Lanzani, \& Marini, 1993; Viganò, 1999), an approach that creates the conditions of understanding (describing/designing) the existing territory through the mapping of its physical elements, a description that can then be used to develop an analysis of the forms of production of these elements and the complexity of their uses: how the city is, formally and socially, built (Secchi, 1989).
\end{abstract}

\section{Keywords}

architecture teaching; city; linear city; Tetouan region; Morocco; urban planning

\section{Issue}

This article is part of the issue "Territories in Time: Mapping Palimpsest Horizons" edited by Chiara Cavalieri (UCLouvain, Belgium) and Elena Cogato Lanza (EPFL, Switzerland).

(C) 2020 by the authors; licensee Cogitatio (Lisbon, Portugal). This article is licensed under a Creative Commons Attribution 4.0 International License (CC BY).

\section{Introduction}

This article focuses on an ongoing pedagogical experience (still in process at the time of writing) developed in a master-level architecture studio at the ULB School of Architecture (Brussels). This experience is being developed in the context of the Grand Tetouan region (North Morocco), a context that allows reflecting upon the concept of the linear city. The interest of this concept lies in the fact that it is both descriptive and project-oriented: descriptive, as this expression can be (and is being) used to define specific forms of linear urban developments; project-oriented, as it has been proposed by several urban planners and/or thinkers, since the expression's coining by Arturo Soria y Mata for its project of linear developments for the extension of Madrid, in the years 1880 (Soria y Puig, 1968). The territory proposed for the study had been the subject, already in 1913, of a proposal for "the first linear city of Africa" by Soria y Mata (the north of Morocco was then under Spanish protectorate, an administration that lasted from 1912 until 1956; see Soria y Mata, 1913). The proposal-which gave birth to the development of a railway infrastructure connecting Ceuta to Tetouan (thoughtlessly dismantled after the end 
of the Protectorate) and initiated a process of urbanization along the coastline-legitimates the use of the concept in the global framework of the urban planning development scheme (Royaume du Maroc, Ministère de l'Aménagement du Territoire de l'Environnement de l'Urbanisme et de l'Habitat, 2017) proposed by the provincial authorities.

The work being developed with the students started in the spring semester of 2019, with an attempt to compare the Tetouan-Ceuta territory with notorious paradigms of linear urban developments (i.e., the via Emilia, in Northern Italy; the swiss shore of the Leman Lake; the Belgian 'noordzee' coast) and linear city projects, realized or not: Soria y Mata's 'ciudad lineal,' in Madrid (Prandi, 2016; Soria y Mata, 1913); Miljutin's, and later Le Corbusier's, projects of industrial linear cities (Cohen, 2002); Victor Bourgeois and Renaet Braem's proposals of linear cities for the Belgian territory (Strauven, 1985; Strauven, 2017); Michel Ecochard's 'combinat' of Casablanca-Fedala (Ecochard, 1951, 1955). The comparison addressed both formal (regarding dimensions, in length and depth; architectural typologies...) and functional (infrastructures, facilities...) issues, focusing on the general idea of spatial distribution and social justice (Secchi, 2013). Students then developed urban and architectural design proposals, based upon congruencies between the existing territory and issues (or principles) identified in the paradigmatic examples studied. The underlying idea was to cross theoretical positions and formal principles with a territory already shaped by its history-with the 'palimpsest' formed by the territory (Corboz, 1983/2001), conceiving an overall project for the linear city of Tetuan as a bead necklace on the existing linear road and highway infrastructure. The students' design proposals, interesting as they were, showed a lack of grip on reality. This led us to set up a semester studio completely devoted to the task of describing how the city is being built, nowadays, using the concept of 'urban material' (Viganò, 1999). This concept, proposed and developed by Paola Viganò and Bernardo Secchi at the turn of the century, constitutes a methodological tool between description and project, as an existing, material reality can be described through the identification of such 'urban materials', while they can, at the same time, be seen as 'building material' for projects (built, or yet to come). 'Urban materials' are the materials that build the urban territory: in this view, their apparition, at specific times, and their use and combination, is what makes up the territory as a palimpsest.

The specific context of the Grand Tetouan region, and its being thought of as a 'linear city,' gives the opportunity to work on the intertwining of urbanism (as discipline) and urbanization (as a phenomenon), and to give the students an understanding of the importance of a disciplinary position that gives equal attention to both. The concept of 'urban material' appears to be particularly effective, not only to develop that understanding but more generally, in a pragmatic way, to work on these issues.

\section{Elements of Conceptualization and Contextualization}

\subsection{A Rapid Overview of the Idea of the Linear City, Project and/or Phenomenon}

The model of the linear city can be traced back to the end of the 19th century and the famous project of 'ciudad lineal' conceived for suburban development in Madrid by Spanish engineer Arturo Soria y Mata (Cohen, 2002; Collins, 1960). This development, structured upon a broad avenue equipped with a tramway line, has been carried on by Soria y Mata's own company. Even though only a small part of the project was built, and though lost its formal characteristics of being a linear urban development standing out in the countryside as it has been completely absorbed by further developments of the city (the neighborhood is still called 'ciudad lineal,' see Cohen, 2002; Collins, 1960), the idea raised great interest. It was soon adopted by urban planners, who saw in it a solution in their quest of rational planning for urban developments in the period of the industrial boom, mainly after World War I-and, therefore, after Soria y Mata's death in 1920 (Prandi, 2016). The success of the concept at the time can be illustrated by the creation of an international association devoted to it, the Association Internationale des Cités Linéaires (International Association for Linear Cities), founded in Paris in 1928 by Georges Benoit-Levy and endorsed by the CIAM (Hall, 2002, p. 117). The most famous sequel of Soria y Mata's concept can be found in Russia and more specifically in the work of Nikolai Miljutine. Jean-Louis Cohen (2002), in his introduction to the second edition of Miljutine's book Sotsgorod, first published in Russia in 1930, describes the strange path the concept of the linear city had taken to reach the soviet country. He underlines the role of the French economist Charles Gide as a passer between Soria y Mata and the Russian urbanists. Gide's 1925 description of the principle of the linear city clearly identifies the issue of:

A city that no longer has a center, where there would no longer be a brain but nerve centers scattered through the length of the backbone, in such a way that each one would have the possibility of staying close to its particular center, its factory, its trading house, these being themselves scattered all along the way. (Charles Gide, 1925, as cited in Cohen, 2002, p. 18, translation by the authors)

The influence of Miljutine's schemes over Le Corbusier, whose role in the diffusion of the concept through the modern architects and urban planning community is well-known, is very clear, despite being the object of debates between the main protagonists (see Cohen, 2002 , p. 29). Le Corbusier's integration of the concept of the linear city in his writings came only after the Second World War, with the publication of Les Trois Etablissements Humains (Le Corbusier, 1945/1959) and 
its famous sketch linking the three 'human settlements': the radio concentric city of exchanges, the industrial linear city and the unit of agricultural exploitation. The interconnection between the three is essential, as it is aimed at protecting the rural, open landscape from the threat of urbanization:

Essential matter of principle nowadays, now that social misadventures together with war risks have encouraged the masters of industry to plan a relocation in terms of dispersion: dispersion of industry in the countryside. The industrial linear city creates, on the contrary, untouched farm reserves. (Le Corbusier, 1959, p. 102, translation by the authors)

Le Corbusier refers explicitly to the 'natural' power of linear infrastructures to attract, and command, urbanization in an incremental way ("the linear city follows a path inscribed in geography," Le Corbusier, 1959, p. 102). The urban development experienced worldwide after World War II has shown how strong this power was. In many places, it indeed assumed linear forms that tend to blur the distinction between the linear city as a project and as a phenomenon:

Although linear planning has never won popular support among professional planners, it has, paradoxically enough, been the natural pattern of growth in our great urban regions. In the USA, a pernicious type of uncontrolled 'linear' or ribbon growth has occurred....Thus, linear growth receives acceptance as a fact, but not as a theory. (Collins, 1960, p. 345)

As Cohen states, concluding his introduction to Miljutine's Sotsgorod: "Dissociated from any revolutionary dimension, the linear city has become a theoretical reference that is rather unclear for the analysis of concrete urban systems in which devices parallel to shores or ways are structuring" (Cohen, 2002, p. 35, translation by the authors). This unclearness is the condition of the work we have developed around the idea of fragmentation: the contemporary linear city can be described as a patchwork of unfinished, fragmentary projects that are incrementally developed (Viganò, 1999).

\subsection{The Context: The Grand Tetouan Region}

The Moroccan territory, as almost all colonized territories of the 19th and 20th centuries, but probably even more clearly than others (see Cohen \& Eleb, 2004), has served as a laboratory for the implementation of innovative urban planning experiences by the colonial powers. It is clearly the case for the territory we are focusing on, where the imposition of a European-centered concept (that of the linear city) collided with the local logic of fabrication and governance of the land (see Boujrouf, 2005).

The Moroccan territory has seen two 'historical' projects of linear cities in the course of the 20th century: the first one, Ceuta-Tetouan, has been described but never drawn, nor built; the second was designed and implemented in 1951 in Casablanca by Michel Ecochard, a major 'modernist' urban planner who was head of the urban planning administration under the French Protectorate from 1946 until 1953; it was later heavily modified by urban developments. Michel Ecochard's influence on Moroccan urban planning practice is related to his invention, the so-called ' $8 \times 8$ grid,' also called the 'Ecochard grid' (see i.e., Avermaete \& Casciato, 2014). The project is presented in an issue of Architecture d'Aujourd'hui (Ecochard, 1951) and in Casablanca: Roman d'une Ville Ecochard (1955) tells the story of his adventures as an urban planner in Casablanca. Cohen describes the project as a "derive from the corbusean lecture of Milioutine" (Cohen, 2002, p. 34).

The territory object of our study stretches along the Mediterranean sea for little more than $30 \mathrm{~km}$, from the Spanish enclave of Ceuta (Ceuta is the Spanish name, Sebta in Arabic transcription), the northern tip of the African continent on the Strait of Gibraltar, to the city of Tetouan, in the South. It consists of a coastal, rather swampy strip, caught between the coast and the foothills that follow it. It is crossed by several natural obstacles, small rivers in the North and, in the South, the Cabo Negro massif and, farther south, the river Martil which connects the old city of Tetouan to the sea, evolving the linear pattern into a Y-shaped figure. Almost completely uninhabited, the littoral lands (plains, wetlands, and dunes along the sea) that used to be considered in pre-colonial times as 'commons,' collective property ('yemaa') for local mountain communities (in particular of the poorest families: Cantarino, 2008), were seen as a blank, open space by the Spanish colonists: an open field for experimentation. It had been considered by Arturo Soria y Mata at the beginning of the 20th century as perfect to host an attempt of the linear city, on the basis of linking the capital of the Spanish Protectorate, the city of Tetouan, to the port city of Ceuta, the main communication gate between the metropolis and its dependency (Soria y Mata, 1913; see Figure 1).

Even though it was pushed forward, after Soria's death, by its main follower Hilarión González Del Castillo under the form of a 'linear garden city' (Del Castillo, 1929), it ended up with the construction of nearly nothing, apart from a railway that was dismantled after the end of the Spanish Protectorate in 1956. Still, this infrastructure, together with the main coastal road, served as support for the development of small urban centers, F'nideq, M'diq, and Martil, later completed by touristic developments from the 1960's onward (the complex process of coastal development, sustained by contradictory governmental decisions, is described under the term of 'littoralization': see Berriane, 1978; Kheddoumi, 2013). The relevance of this dimension is acknowledged by the growing number of recent planification and governance tools specifically dedicated to this issue, from 


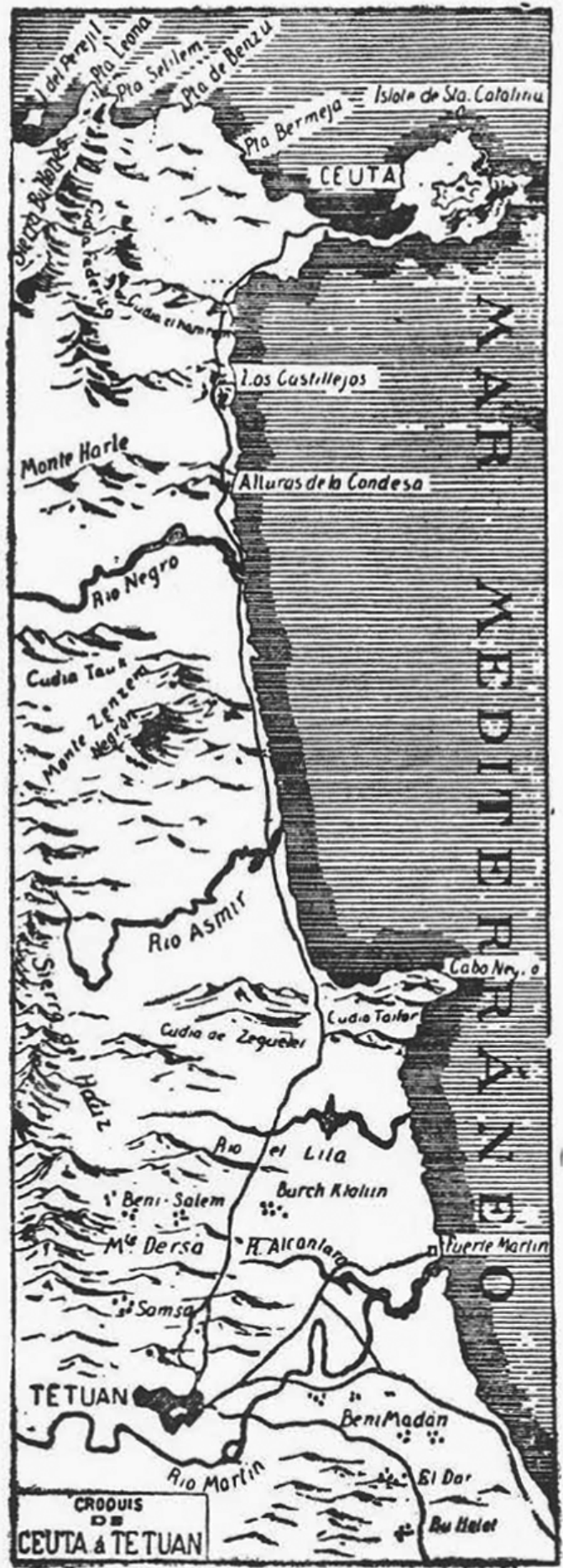

Croquis de la región que se extiende entre Ceuta, plaza de nuestra soberania, y Tetuán, capital de nuestro Protectorado, en que puede verse lo fácil, lo tentadora y lo hermosisima que sería una ciudadjardín-lineal oriental que uniera sin solución de continuidad aquellas dos ciudades existentes y que se prolongara por la campiña marroqui frente al encantador Mediterráneo.

Figure 1. Map of the Grand Tetouan region. Source: Del Castillo (1929). the Schéma Directeur d'Aménagement Urbain du Littoral Touristique Tétouanais (Ministère de l'Aménagement du Territoire de l'Environnement de l'Urbanisme et de I'Habitat, 1998) to the Schéma Directeur d'Aménagement Urbain et Plan de Zonage du Littoral Touristique Méditerranéen de Tanger et de Tétouan (Royaume du Maroc, Ministère de l'Aménagement du Territoire de l'Environnement de l'Urbanisme et de l'Habitat, 2004), or the Programme de Développement Touristique Tamuda Bay-Tetouan 2009-2013 (Royaume du Maroc, Ministère du Tourisme, 2008).

Besides tourism politics, another driving force for a linear urban development along the coast, probably more powerful (or insidious) than the first one in terms of dynamics, is the presence of the Spanish enclave of Ceuta in the North end of the territory. Cross-border dynamics, i.e., informal trade and smuggling, have highly affected the urbanization and socio-economic patterns of development of the coast (and touristic developments are of course part of this process).

The recognition of the reality of the linear city is currently acknowledged by the decision to create a level of strategic planning and administration that coincides with the geographic territory for the metropolitan region of the Grand Tetouan (the term 'metropoli$\tan ^{\prime}$ is here essential, as it recognizes the interaction between the different parts of the region in a metropolitan way; Royaume du Maroc, Ministère de l'Aménagement du Territoire de l'Environnement de l'Urbanisme et de I'Habitat, 2017). The spatial development scheme, called SDAU, for the Grand Tetouan identifies issues and challenges for the future. It recognizes the conurbation between Tetouan and Martil, along the river Martil, as a fact, and proposes schemes for a more balanced (or less anarchic) and more ecologically conscious development along the coastline. It creates the conditions for the reflection on the Grand Tetouan as a linear city in a transhistoric way by re-assessing the project of the linear city through a prism in which industry (the driver of the modern paradigm of the linear city) is replaced by the tourism industry. The project-oriented themes then become those of the post-industrial city as a whole (Ascher, 2001): How to deal with urban dispersion and social justice (Secchi, 2013)? How do we integrate environmental issues and agricultural practice in a metropolitan reality? How can we address the issue of intensification of urban activities in a metropolitan, scattered environment (Amphoux, 1999)? How can the informal economy, and informal settlements, be taken into account, and used as material tools of development? The interest of the work lies in the reactivation of a formal, theoretical concept, that of the linear city, in a multi-layered, palimpsest-like, territory: is the concept still relevant? The connection between spatial patterns and changing socio-economical uses of the territory is crucial here. 


\section{An Attempt to Describe}

To deal with these issues, after having developed the first approach based on the comparison of the territory with paradigms of linear city/developments, we realized it was necessary to take a step back and assume a position Bernardo Secchi and Paola Viganò had denominated 'descriptive anxiety' (Viganò, 1999, p. 21). It meant going back, explicitly, to the 'descriptive season' of Italian architecture schools of the late 20th century (see, i.e., Boeri et al., 1993; De Rossi, Durbiano, \& Governa, 1999; Macchi Cassia, 1998; Munarin \& Tosi, 2001; Secchi, 1989, 2001; Viganò, 1999). The idea was to consider the territory we had to be working on as completely new, unknown (or to consider ourselves as strangers to the context), going back to a proposal made by Cohen (1987):

It is at the same time a work on geometries, urban layout and physical components of the city that need to be done, in a disciplinary void situated at the border of the territory conventionally assigned to the architect, and that of other, diverse technical disciplines operating in the realm of the city. (p. 54, translation by the authors)

We based our investigation on the concept of 'urban material.' This concept is defined by Paola Viganò in her book La Città Elementare, in an analogy with music, as 'anything that can be combined in a composition; anterior compositions can become materials for a new composition, and if there was to be more than one world, each and every one of these would be a material' (Viganò, 1999, p. 206). It is clearly related to the Italian school of typo-morphological analysis, but with a clearer link to the project-oriented dimension. It is de- scribed by Viganò as 'a step backward from typological studies.... It is about building up a sort of 'pending vocabulary' (Leroi-Gourhan) that tries not to lock in predetermined categories what might emerge, but might as well not emerge' (Viganò, 1999, pp. 39-40).

We divided the territory into twelve study areas that can be described as 'periurban,' where we put this descriptive approach into practice with a group of twentyfive students. We did not include in our study dense, historic urban fabric, as its analysis requires other methodological tools (we considered it as an urban material as a whole, without fragmenting it). The goal was to establish an inventory of urban materials of the areas and the attribution of names for every class of material. It proved to be a very complicated task for the students, as it requires negotiating between specificity, particularity, and genericity, and agreeing on scales of analysis. As Viganò, quoting Wittgenstein, puts it, the question of scale is of particular difficulty:

Defining the constitutive parts of reality is, as was shown by Wittgenstein, rather complicated: "What are the constitutive parts of a chair? The pieces of wood that form it? Or the molecules? Or the atoms? Simple means: not composed. And that's where the difficulty lies: composed, in what sense?" (Wittgenstein, 1953, as cited in Viganò, 1999, p. 31, translation by the authors; Figures 2 and 3 )

The notion of urban material implies that each material has to be considered as an artifact, or a grammatical element of the 'text' given us to read. This relates to the Italian tradition of typo-morphological analysis and its structuralist background (see for instance the various letture di città-literally 'readings of cities'-it

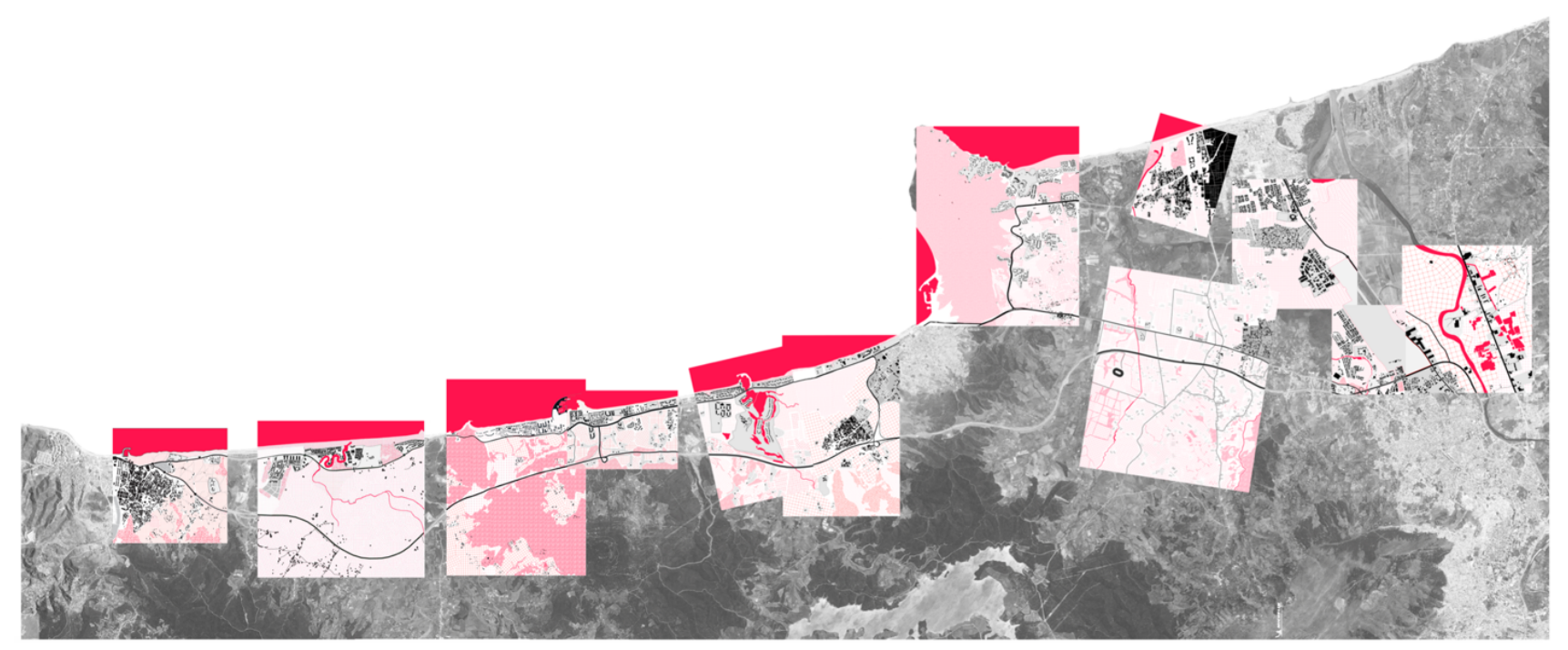

Figure 2. Grand Tetouan region: Synthetic map of the urban materials. Note: The graphic expression of the overall cartography was based on the one developed by Cesare Macchi Cassia's team in the study they realized on Milan in the late 1990s (Macchi Cassia, 1998). Source: Terrains d'Architecture, Master in Architecture Design Studio (2019). 

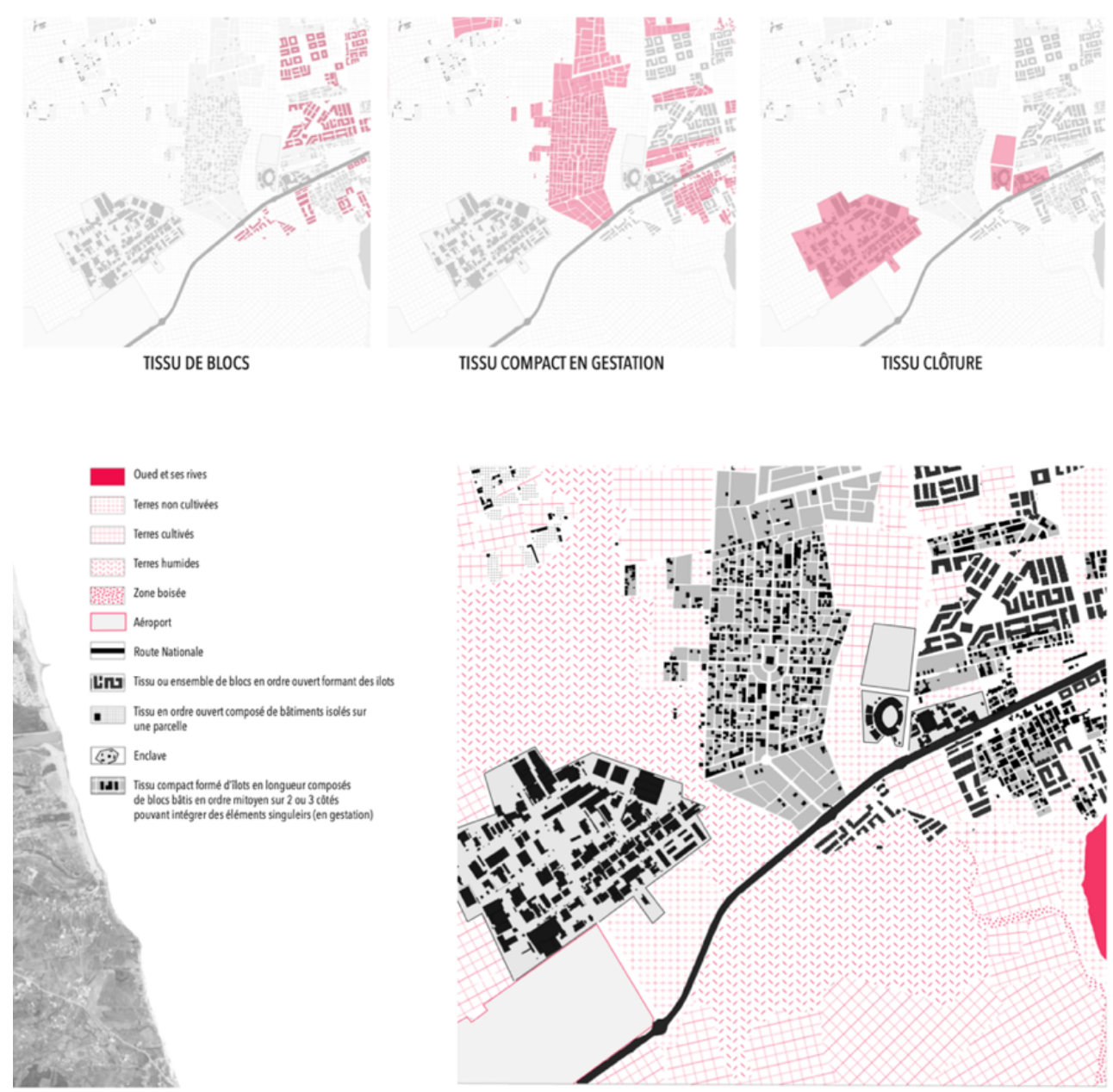

Figure 3. Grand Tetouan region: Synthetic map of the urban materials, close-up of the Oum-Kaltoum area with corresponding legend. Source: Terrains d'Architecture, Master in Architecture Design Studio (2019).

generated, i.e., Berardi, 1970; Caniggia, 1963; Caniggia \& Malfroy, 1986; Muratori, 1959; Panerai, Depaule, \& Demorgon, 1999), and to the notion of the territory as a palimpsest developed by André Corboz: "The territory is the object of a construction. It is a sort of artifact. It constitutes therefore also a product" (Corboz, 2001, pp. 213-214, translation by the authors).

There is a clear link between this idea of territory as an artifact, or product, and the notion of urban material, as urban materials, artifacts themselves, can be seen as the pieces that 'build up' this territory. In pedagogical and scientific terms, a central idea in which to think the process of fabrication of this 'territory as a product,' is the concept of operation. The term operation can be understood in two different ways: as a composition, in Wittgenstein's sense (see Viganò, 2002, p. 31); but also, in a more disciplinary, pragmatic way, as development, in the urban planners' terminology: as a project. It allows the architecture students to understand that there is a clear relationship between description and project, on the one hand, and that the project itself is carried out, or even built, by different actors, the architect being only one of those (and certainly not the main one, against what is usually taught to architecture students: working in Morocco is, in this sense, very helpful, as inhabitant-driven self-construction and development is still very much present). The 'territory as a palimpsest' view also consents to understand or read the territory as a superposition of different projects. Going back to our work on the Grand Tetouan's urban material, it means that these can be viewed as superposed fragments of different projects, interacting on the territory and creating a specific urban phenomenon (Rossi, 1990, p. 232). One of these projects is del Castillo's linear city: Even though it wasn't built as such, the idea in some way still haunts the territory. As Aldo Rossi puts it:

Projects have a proper existence, like built architectures; they are elements of a whole that is the real.... [A project is real] in that it generates afterward a series of facts that can be explained only by its presence, meaning by its shape." (Rossi, 1990, p. 242)

Methodologically, we have proceeded in three phases. After having identified the twelve study areas, each group of students worked based on aerial photographs 
to identify formal recurrences. This preliminary work was completed by an analysis of historical maps that gave a diachronic view of the evolution of the territory and led to a description of the territory in time-related layers (see i.e., De Rossi et al., 1999). The group of students then went on a ten-day fieldwork trip to Morocco, during which they confronted their first deductions with reality. Also, they were asked to work on the concept of operation, by trying to get information about what was called 'biography' of places. This survey was completed in meetings with local actors (architects, planners, professors, developers, and of course the Agence Urbaine du Grand Tetouan, the local planning agency) which helped the students better understand the variety of operations (see Figure 4).

The historical, diachronic approach intended to identify the chronology of apparition and, possibly, the spreading of specific urban materials on the territory. It showed a growth pattern characterized by discontinuity: more a leopard-coat-like pattern than a more classical oilstain one (the influence of the city center of Tetouan is not relevant), revealing the influence of road infrastructures in the distribution of urban materials, and an economy driven by exogenous forces (mainly, the tourism industry and the presence of Ceuta as a source of informal economy and real estate speculation). In terms of urban materials, this process of growth is characterized by a limited number of artifacts or forms, and mainly based on two elements: the road infrastructure, on the one hand (very helpful in this regard to pay attention to $\mathrm{mi}$ nor urban materials, such as lines of palm trees, or a specific street light and their combination), and on the other hand, the land plot as a unit for the fabrication of the territory, be it large (in the case of tourism or planned housing developments) or small (in the case of private housing operations, i.e., informal settlements). These considerations consolidate the interest of working on urban material in terms of operations, in which one or more urban materials can be used and combined.

The whole work has led, at this point, to the realization of an overall map (see Figure 2) that identifies urban material at the territorial scale and, for each area, an analysis of how urban materials form system (i.e., roadway and built material) and a focus on specific types of operations (each area being characterized by the preponderance of a certain type, or, in historically more stratified areas, by a complex combination of operations). The synthesis map shows the 'leopard coat' pattern, rather complex, made of road systems, enclaves, incremental self-built housing neighborhoods, planned housing developments, and industrial compounds, with bits and pieces of left-over natural reserves, wetlands, and fields.

Without going into detail about the whole study, a few elements may be highlighted:

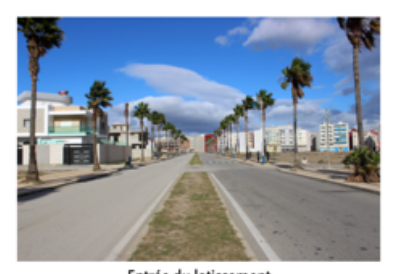

Entrée du lotissement

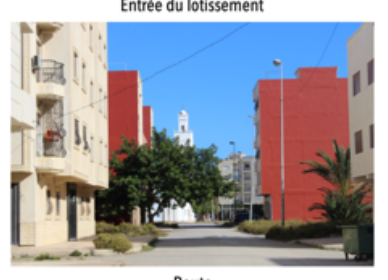

Route
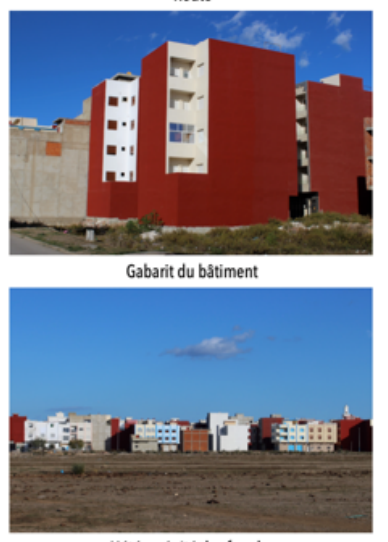

Hétérogénité des façades

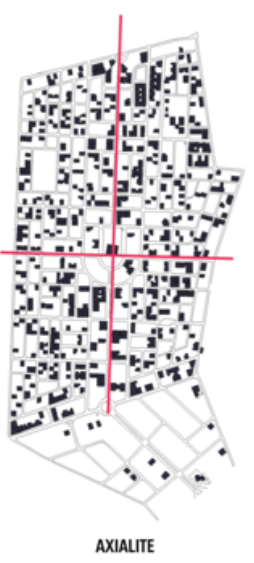

AXIALITE

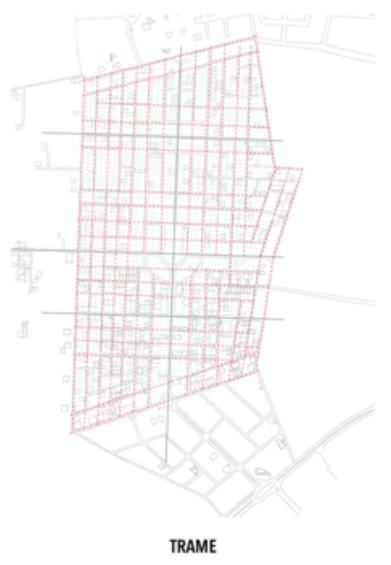

TRAME

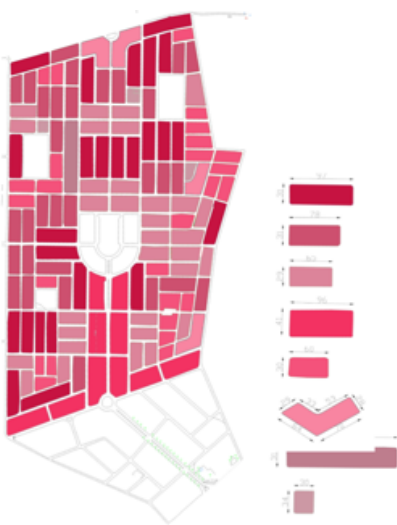

DIMENSION DES ILOTS PRESENTS
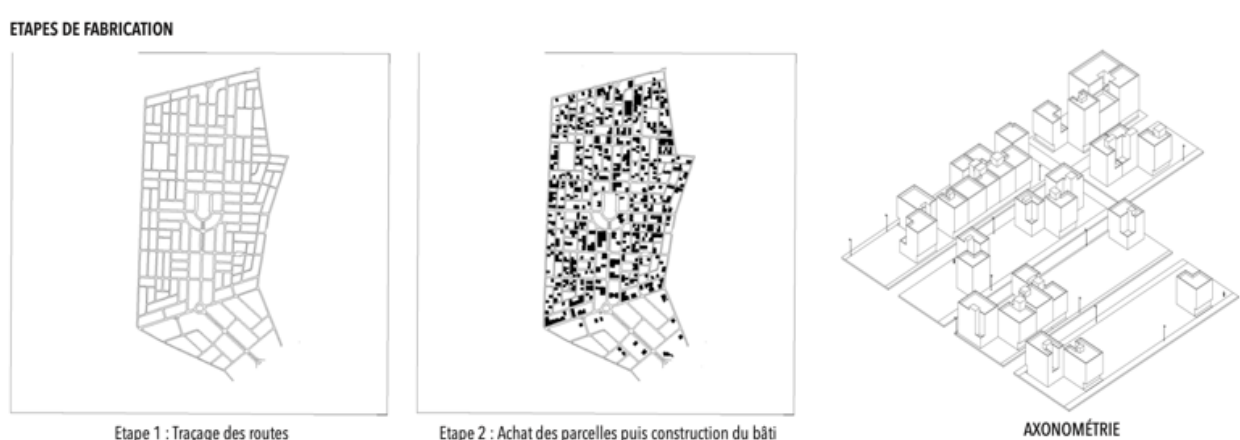

Figure 4. Grand Tetouan region: Example of the urban material, Oum Kaltoum area. Source: Terrains d'Architecture, Master in Architecture Design Studio (2019). 
1. The influence of the geographical substrate and preexistences (built or functional, i.e., agrarian use) is very strong; for instance, topography, swamps and rivers, and land division dictate the development in many ways. Similarly, the presence of urban centers ( $F^{\prime}$ nideq, M'diq, Martil) and leisure resorts act as catalysts for developments. The linear configuration is mainly linked to these natural, original characteristics, and very little to a "linear city" project-oriented vision. Specifically, the idea of a linear city in line with the modernist project experience in which tourism would act as industry and driver for the local economy and social practices is absent in terms of formal composition and configuration. There is neither reflection upon complementarity or mutualization whatsoever, nor upon the forms of tourism. The only urban material reference is the enclave, each selfcentered, with a variety of 'formal fillings' (villas, apartment blocks, rows of houses) but absolutely no consideration for the public realm as a whole: it constitutes an issue for the future of this territory.

2. As for the 'urban materials,' the territory is fundamentally characterized by the contiguous presence of elements that tend not to work together as a system. A predominant material on the coastline is that of the enclave, touristic and residential closed compounds that work with the main road, slowly eating up the open spaces and blocking access to the seashore. The urban character of this fabric is questionable in terms of density, facilities, and social diversity; the enclave as an operation is also found in some areas that can be considered more urban (closer to densely-built city centers). Other elements making up major developments in the territory are self-built areas, characterized by square lots incrementally forming city blocks, on the one hand, and private developers blocks (either social, middle or high class) that include all the infrastructure facilities (roads, sewage, lighting, vegetation, and urban furniture) on the other. This last type of operation tends to be problematic as it more often addresses financial speculation than real needs.

3. The territory functions, in many respects, as a linear city: the presence of linear infrastructural elements (road, highway, disused railway) influences the distribution of 'urban materials' along the coast. Inhabitants make it work as one 'city,' i.e., in terms of choice of location (to live and/or work). This allows us to complement the formal description of the territory based upon the notion of urban material with that of practice: the territory is produced not only by materials but also, and mainly, by the uses and practices of its inhabitants, in terms of mobility, socio-economic and leisure activities, etc. In this respect, it should be underlined that the linear city as it has been pro- duced, in an incremental, rather unplanned way, creates an urban reality characterized by social unbalance: the territorial distribution of facilities, mobility (with a very poor system of public transportation), the access to basic needs like water or education, are real issues for the future, and question the model of the linear city itself. The emergence of controversies on important environmental and social issues (as in the case of the destruction of the Smir Lagoon some years ago, to build a touristic resort, or the recognition of the existence of "fragile" minorities, such as Sub-Saharan African people in the area) demonstrates the growing social awareness of the territory that has to be taken into account by the authorities.

\section{Conclusions}

The main issues regarding the future of the Grand Tetouan territory concerning the hypothesis of consolidating a linear city scheme of development are the environmental issue (how can a balance between built and open space be maintained, taking into account the climate change that will affect the water system) and the social issue (how to cope with the tendency towards a socially segregated territory, i.e., in terms of spatial justice). The linear development scheme can address these issues, in accordance with some of the principles developed by modernists. Specifically, longitudinally, the idea of considering the linear city as a necklace of varied urban situations, where diversity of uses and population can be enhanced, separated by green buffer zones (as envisaged by the SDAU), linked by an efficient, metropolitan railway system; transversally, by assuring a complementarity between the inland countryside and the coastal developments, also by working on a transversal road system.

The linear city scheme is nowadays somehow contradicted by a project of developments on the Martil river banks, following the model of other Moroccan cities (i.e., the developments being built in the Bou Regreg Valley between Rabat and Salé). We have seen that the conurbation movement between the two cities of Tetouan and Martil is on its way. It can still be controlled, but it certainly is not a good option to opt for the urbanization of the valley, which constitutes a flood risk area. In this regard, the linear city scheme, developing northward along the coast, can be a pertinent alternative. What is obvious is that both options are to be considered as incompatible.

Recognizing, through description, the permanence of the linear pattern in the developments of the Grand Tetouan region is important. But as André Corboz puts it, describing is also envisioning the future:

There can't be a description of the territory without an idea of that territory, an idea which filters the relevant features, confronts the qualities, and assigns di- 
mensions and values and neglects characters which another idea of the territory might retain as important. (Corboz, 2001, translation by the authors)

The work has shown that there is a need for projectoriented input on the very idea of the linear city, in terms of urban material. Apart from the roadway system, which shows a clear pattern of linearity, the described urban materials (and more specifically, the predominance of the enclave) do not show any specific way of "building up" a linear city.

The incremental logic of growth has led to a necklacelike structure that does not show any understanding of the specific qualities of the idea of a linear city, and its capacity to meet the need for social justice. More specifically, the integration of tourism as an industry needs to be confronted by the project, as for now, it has only created social segregation and spatial inequities.

This will necessarily include, in terms of a project, a reflection upon the integration of an efficient, linear, public transportation system, with new forms of urbanity based on social needs. This is the next step, not only for the work of our students but for the local planning authorities: what kind of urban materials can be created and composed to address these issues?

We have tried to show, through our work on the specific case study of Tetouan, how the palimpsest approach to contemporary territories can be enriched by intertwining it with the notion of the project, be it at large (the linear city pattern) or smaller scale (through the use of the notion of "urban material," and its connection to that of "operation"). The idea of the project as the transformation of pre-existing (natural, built, or socio-economical) structures is essential to understand the link between the layers of the palimpsest. The project transforms the pre-existing layers (the "substrate") but is also informed by the elements that constitute these previous layers. Unbuilt or unachieved projects (i.e., that of the linear city) can also act as conceptual structures for future developments.

\section{Acknowledgments}

Our acknowledgements go to the partner institutions in this project: the School of Architecture of Tetouan (ENAT) and especially its director, Hakim Cherkaoui; the Urban Planning Agency of the Great Tetouan, and especially Mr Rachid Amerniss; the School of Architecture of Marseille (ENSAM), more specifically the studio of Laurent Hodebert, and the School of Landscape Architecture of Marseille-Versailles (ENSP), Jean-Baptiste Lestra; the French Agency for Sustainable Mediterranean Cities and Territories (AVITEM-Agence des Villes et Territoires Méditerranéens Durables), and especially its director of strategy, Marie Baduel; and of course, last but not least, our students: Yacine Abdelghenine, Myriam Ait Ouhmane, Zuleyha Bayat, Célia Birlouez, Ronny Campos Pereira, Maxime Davy, Sophie Decock, Nana-Tao
Djiteye, Najib El Barmaqui, Melodi Ertugrul, Mohamed Hahati, Eugénie Le Merle-Viguie , Manuel Lequarré, Ivan Lucas, Sarah Mortada, Marika Nesterowicz, Célia Niyibaho, Abdellah Sadoune, Salim Saidi, Nicolas Schiltz, Ionela Stefan, Aleksandar Stoimenov, Katja Winderickx, Sherihane Zamour-Ifar, Imane Zaoujal.

\section{Conflict of Interests}

The authors declare no conflict of interest.

\section{References}

Amphoux, P. (Ed.). (1999). La densité urbaine. Du programme au projet urbain [Urban Density. From program to Urban Design] (Rapport de Recherche $n^{\circ}$ 142). Lausanne: EPFL.

Ascher, F. (2001). Nouveaux principes de l'urbanisme. La fin des villes n'est pas à l'ordre du jour [New principles of urban planning. The End of cities is not on the agenda]. La Tour d'Aigues: Editios de l'Aube.

Avermaete, T., \& Casciato, M. (2014). Casablanca Chandighar: Bilans d'une modernisation [Casablanca Chandighar: Outcomes of a modernization]. Montreal and Zurich: CCA/Park Books.

Berardi, R. (1970). Lecture d'une ville: La medina de Tunis. L'Architecture d'Aujourd'hui, 153, 38-43.

Berriane, M. (1978). Un type d'espace touristique Marocain, le littoral Méditerranéen. Revue de Géographie du Maroc, 2, 5-26.

Boeri, S., Lanzani, A., \& Marini, E. (1993). Il territorio che cambia-Ambienti, paesaggi e immagini della regione Milanese [The territory that changes. Environments, landscapes and images of the Milan region]. Milano: Segesta.

Boujrouf, S. (2005). Innovation et recomposition territoriale au Maroc: Une mise en perspective géohistorique [Innovation and territorial recomposition in Morocco: A geo-historical perspective]. In B. Antheaume \& F. Giraut (Eds.), Le territoire est mort: Vive les territoires! Une refabrication au nom du développement [The territory is dead: Live the territories! A reconstruction in the name of development] (pp. 133-156). Paris: IRD.

Caniggia, G. (1963). Lettura di una città: Como [Reading of a city: Como]. Roma: Centro Studi di Storia urbanistica.

Caniggia, G., \& Malfroy, S. (1986). L'approche morphologique de la ville et du territoire [The morphological approach to the city and the territory]. Zurich: EPFZ.

Cantarino, C. M. (2008). Colonialismo y transformación del paisaje en el litoral tetuaní: Aportación del análisis histórico a la comprensión de los problemas ambientales actuales [Colonialism and transformation of the landscape on the tetouan coastline: Inputs of the historical analysis for the understaning of contemporary environmental issues]. In E. Taiqui, E. A.Jiménez, 
\& M. Youbi Idrissi (Eds.), Conservación y valorización de Koudiat Taifour. Tétouan: Imprimerie Al Khalij Al Arabi.

Cohen, J. L. (1987). Forme urbaine et discontinuité [Urban form and discontinuity]. In Métamorphoses de la ville. Crise de l'urbain, futur de la ville [Metamorphosis of the city. Crisis of the urban, future of the city] (pp. 51-58). Paris: Ed. Economica.

Cohen, J. L. (2002). Le commissaire prend le crayon [The curator grabs the pencil]. In N. Milioutine (Ed.), Sotsgorod: Le problème de la construction des villes socialistes [Sotsgorod: The problem of constructing the socialist cities]. Besançon: Editions de l'Imprimeur.

Cohen, J. L., \& Eleb, M. (2004). Casablanca: Mythes et figures d'une aventure urbaine [Casablanca: Myths and figures of an urban adventure]. Paris: Hazan.

Collins, G. R. (1960). Cities on the line. Architectural Review, 765, 341-345.

Corboz, A. (2001). Le territoire comme palimpseste et autres essais [The Territory as Palimpsest and Other Essays]. Besançon: Editions de l'Imprimeur. (Original work published 1983)

De Rossi, A., Durbiano, G., \& Governa, F. (1999). Linee nel paesaggio. Esplorazioni nei territori della trasformazione [Lines in the Landscape. Explorations in the Territories of Transformation]. Torino: UTET.

Del Castillo, H. G. (1929). La colonizacion de Marruecos: La ciudad-jardin-lineal-Ceuta-Tetuan como negocio industrial [Colonization of Morocco: The Ceuta Tetouan Linear Garden City as industrial business]. Revista Hispano-Africana, VIII(2).

Ecochard, M. (1951). Problèmes d'urbanisme au Maroc [Urban planning issues in Morocco]. L'Architecture d'Aujourd'hui, 35, 9-11.

Ecochard, M. (1955). Casablanca, le roman d'une ville [Casablanca, the novel of a city]. Paris: Ed. de Paris.

Hall P. (2002). Cities of tomorrow. An intellectual history of urban planning and design in the twentieth century (3rd ed.). Malden, MA: Blackwell Publishing. (Original work published 1983)

Kheddoumi, I. (2013). Littoralisation et tourisme au nord du Maroc [Littoralization and tourism in the north of Morocco] (Unpublished Master dissertation). Faculté d'architecture, ULB, Brussels.

Le Corbusier. (1959). Les 3 établissements humains [The three human settlements]. Paris: Editions de Minuit. (Original work published 1945)

Macchi Cassia, C. (Ed.). (1998). Il progetto del territorio urbano [The project for the urban territory]. Milan: Franco Angeli.

Munarin, S., \& Tosi, M. C. (2001). Tracce di città. Esplorazioni di un territorio abitato: L'area veneta [Traces of city. Explorations of an inhabited territory: The Veneto area]. Milan: Franco Angeli.

Muratori, S. (1959). Studi per una operante storia urbana di Venezia [Study for an effective urban story of Venice]. Rome: Libreria dello Stato.

Panerai, P., Depaule, J. C., \& Demorgon, M. (1999).
Analyse urbaine [Urban analysis]. Marseille: Parenthèses.

Prandi, E. (2016). L'architettura della città lineare [The architecture of the linear city]. Milan: Franco Angeli.

Rossi, A. (1990). L'architecture de la ville [The architecture of the city]. Paris: LEC. (Original work published 1966)

Royaume du Maroc, Ministère de l'Aménagement du Territoire de l'Environnement de l'Urbanisme et de I'Habitat. (1998). Schéma directeur d'aménagement urbain du littoral touristique Tétouanais [Urban Planning Scheme for the touristic coastline of Tetouan]. Rabat: Ministère de l'Aménagement du Territoire de I'Environnement de l'Urbanisme et de l'Habitat.

Royaume du Maroc, Ministère de l'Aménagement du Territoire de l'Environnement de l'Urbanisme et de l'Habitat. (2004). Schéma directeur d'aménagement urbain et plan de zonage du littoral touristique Méditerranéen de Tanger et de Tétouan [Urban planning scheme and Zoning scheme for the Mediterranean touristic coastline of Tetouan and Tanger]. Rabat: Ministère de l'Aménagement du Territoire de l'Environnement de l'Urbanisme et de l'Habitat.

Royaume du Maroc, Ministère de l'Aménagement du Territoire de l'Environnement de l'Urbanisme et de l'Habitat. (2017). Schéma directeur d'aménagement urbain du Grand Tétouan, phase 1: Analyse territoriale et enjeux de développement [Urban planning scheme for the Grand Tetouan, phase 1: Territorial analysis and development issues]. Rabat: IAU-IdF/Ministère de I'Aménagement du Territoire National, de I'Urbanisme, de I'Habitat et de la Politique de la Ville, Royaume du Maroc.

Royaume du Maroc, Ministère du Tourisme. (2008). Programme de développement touristique Tamuda Bay-Tetouan 2009-2013 [Program of Tourism Development Tamuda-Bay-Tetouan]. Rabat: Ministère du Tourisme.

Secchi, B. (1989). Un progetto per l'urbanistica [A project for urban planning]. Torino: Einaudi.

Secchi, B. (2013). La città dei ricchi e la città dei poveri [The city of the rich and the city of the poor]. Roma and Bari: Laterza.

Secchi, B. (2001). Prima lezione di urbanística [First lesson of urban planning]. Roma and Bari: Laterza.

Soria y Mata, A. (1913). La primera ciudad lineal africana entre Ceuta y Tetuán [The first African linear city between Ceuta and Tetouan]. La Ciudad Lineal, 513, 65-66.

Soria y Puig, A. (1968). Arturo Soria y la ciudad lineal [Arturo Soria and the linear city]. Madrid: Revista de Occidente.

Strauven, F. (1985). René Braem: Les aventures dialectiques d'un moderniste flamand [The dialectical adventures of a flemish modernist]. Brussels: AAM.

Strauven, I. (2017). Victor Bourgeois (1897-1962): Architecture and neutrality. Rotterdam: nai 010 Publishers. 
Terrains d'Architecture, Master in Architecture Design Studio. (2019). Students production, unpublished. Brussels; ULB.

\section{About the Authors}

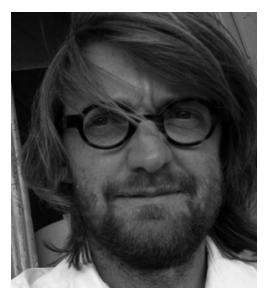

Victor Brunfaut (Architect, ISA La Cambre, Brussels, 1991; PhD in Urban Planning, La Sapienza Roma/Pescara, 2003) teaches at the Faculté d'architecture La Cambre-Horta, Université libre de Bruxelles. He has been running the master architectural and urban design studio called "Terrains d'architecture" for more than ten years, in collaboration with Bertrand Terlinden and the anthropologist Graziella Vella. He is a member of the Research Center HABITER.

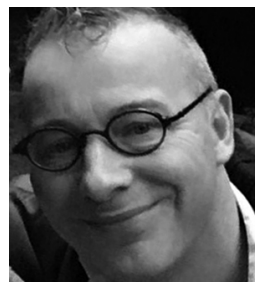

Bertrand Terlinden (Architect, ISA La Cambre, Brussels, 1987; PhD in architecture, IUA Venezia, 1996) teaches at the Faculté d'architecture La Cambre-Horta, Université libre de Bruxelles. He has been running the master architectural and urban design studio called "Terrains d'architecture" for more than ten years, in collaboration with Victor Brunfaut and the anthropologist Graziella Vella. He is a member of the Research Center HABITER. 